\title{
DIÁRIOS DE CONFINAMENTO: A EMERGÊNCIA DO NOVO NA INTIMIDADE DA RELAÇÃO EU-OUTRO-MUNDO
}

\author{
DIARIOS DE CONFINAMIENTO: LA EMERGENCIA DE LO NUEVO \\ EN LA INTIMIDAD DE LA RELACIÓN TO-OTRO MUNDO \\ CONFINEMENT DIARIES: THE EMERGENCY OF THE NEW \\ IN THE INTIMACY OF I-OTHER-WORLD RELATIONSHIPS
}

\author{
Marina Assis Pinheiro ${ }^{1}$ e Roberta de Sousa Mélo² \\ ${ }^{1}$ Universidade Federal de Pernambuco, Recife/PE, Brasil \\ ${ }^{2}$ Universidade Federal do Vale do São Francisco, Petrolina/PE, Brasil
}

\begin{abstract}
RESUMO: Este trabalho discute e caracteriza as dinâmicas subjetivas e intersubjetivas das relações eu-outro(a)-mundo próprias à experiência íntima de confinamento domiciliar, a partir de diários textuais produzidos por três mulheres confinadas durante a pandemia. A partir da análise dialógica dos dados identificaram-se três estilísticas da intimidade confinada: a "introspecção da deriva"; a "performativa" e o "subjetivismo de fresta". Estas alegorias dialógicas lançam luz sobre: (a) os principais impasses na manutenção das formas de vida pré-virais; (b) as ambiguidades enunciativas e ambivalências afetivas na construção de alternativas ao período de confinamento na dinâmica ser-com-os-outros e os-outros-em-mim; (c) as formas de vivência do tempo, na reconstrução do passado, nos modos de elaboração de futuros através também das intensidades do presente.

PALAVRAS-CHAVE: Intimidade; Corpo; Pandemia Covid-19; Desamparo; Dialogismo.
\end{abstract}

RESUMEN: Este artículo discute y caracteriza la dinámica subjetiva e intersubjetiva de las relaciones entre el yo, el otro(a) y el mundo que son específicas de la experiencia íntima del confinamiento en el hogar, basado en diarios textuales producidos por tres residentes del Estado de Pernambuco, confinados durante la pandemia. A partir del análisis dialógico de los datos, se identificaron tres características de la intimidad confinada: la "introspección de la deriva”; el "performativo" y el "subjetivismo de brecha”. Estas alegorías dialógicas arrojan luz sobre: (a) los principales impases en el mantenimiento de formas de vida pre-virales; (b) las ambigüedades enunciativas y las ambivalencias afectivas en la construcción de alternativas al período de confinamiento en la dinámica ser-con-otros y otros-en-mí; (c) las formas de experimentar el tiempo, en la reconstrucción del pasado, en las formas de elaborar futuros a través de las intensidades del presente.

PALABRAS CLAVE: Intimidad; Cuerpo; Pandemia de Covid-19; Impotencia; Dialogismo.

ABSTRACT: Based on textual diaries produced by three women confined at home during the pandemic, this article discusses the subjective and intersubjective dynamics of self-other-world relationships that are part of the intimate experience of home confinement. From a dialogical analysis of the data, three stylistics of the confined intimacy were identified: the drift's introspection; the performative and the slot subjectivism. These dialogical allegories shed light on: (a) the main impasses in the maintenance of pre-viral lifeforms; (b) the declarative ambiguities and affective ambivalences in the construction of alternatives to the period of confinement in the dynamics being-with-the-others and the-others-in-me; (c) the ways of experiencing time in the reconstruction of the past, in the ways of elaborating futures also through the intensities of the present.

KEYWORDS: Intimacy; Body; Covid-19 pandemic; Helplessness; Dialogism. 


\section{Introdução}

No ineditismo insólito e coletivo da vivência da pandemia atual, a arena cultural de vozes sociais (Bakhtin, 1990, 1999, 2006) debruça-se, de forma conflituosa e tensa, sobre a construção de sentidos acerca das formas de vida humanas e ecossistêmicas. O evento viral e indeterminístico do novo coronavírus provocou uma profunda descentração na humanidade sobre seus modos de consumo, produção e relação com o ambiente, sobre suas políticas mais ou menos potencializadoras de algum registro para a solidariedade (Rorty, 1990, 1993). Há, nesse mesmo panorama, uma ressignificação dos vínculos e das formas de sociabilidade ocasionada pelas recomendações de distanciamento social, o que nos conduz ao interesse pelos sentidos produzidos pelas pessoas quando do confronto consigo mesmas ao longo das vivências do confinamento doméstico.

O presente trabalho pretende, assim, discutir e caracterizar as dinâmicas subjetivas e intersubjetivas das relações eu-outro(a)-mundo próprias à "experiência íntima" de confinamento domiciliar em decorrência da pandemia da Covid-19, a partir de diários textuais oriundos da pesquisa desenvolvida por Marina Pinheiro e Roberta Mélo (2020). Neste universo, o artigo aborda as mutações culturais inerentes às esferas subjetivas e intersubjetivas atuantes na reconstrução do cotidiano e suas regulações simbólico-afetivas.

Ao se tomar como referência a noção de que os/as agentes sociais conhecem o mundo através de seus corpos (Lisdero, Brandan, Pellón, \& Dubois, 2017), entende-se que o distanciamento físico recomendado por especialistas e autoridades políticas, ao conduzir à suspensão das nossas regras elementares de sociabilidade, tem trazido impactos marcantes às dinâmicas do perceber e do ser percebido. Consequentemente, essas ressonâncias também adentram o campo das relações eu-outro(a)-mundo. Logo, há uma demanda posta pelas configurações sociais atuais em direção às esferas da subjetividade e da intersubjetividade. Uma vez recolhidos(as) à intimidade da vida doméstica, assumindo as restrições do contato físico com o(a) outro(a), somos mobilizados(as) a nos reencontrarmos em alguma medida, a insistirmos em nossa construção biográfica.

Partimos do pressuposto de que os conteúdos do vivido no cotidiano da pandemia sinalizam novas significações de nosso entrelaçamento com o mundo, ao mesmo tempo em que nos confrontam com o que Judith Butler (2019) entende como "solicitações éticas" de caráter global que emergem em nossas relações de proximidade, mas também nas de nosso distanciamento. De acordo com a autora, os imaginários das fronteiras pelos quais definimos nossos lugares nos convocam a refletir sobre nossa implicação com o sofrimento da outridade, estando ela perto ou distante. Questões como essa nos parecem despontar mais incisivamente a partir da instauração do confinamento domiciliar enquanto medida recomendada em caráter de urgência para o enfrentamento da pandemia da Covid-19 em nossa sociedade. Em primeiro lugar, porque a eficácia dessa estratégia depende, desde o início, da adesão de cada cidadão/cidadã a uma dinâmica de reelaboração de suas identificações com o(a) outro(a). Sobretudo, de reconhecer-se globalmente ao mesmo tempo em que deve conscientizar-se do valor de suas ações individuais, de afetar o mundo e de saber-se diretamente afetado, em suas vivências mais íntimas, pelas respostas das demais pessoas às demandas da nova realidade.

Assim, se essa realidade se institui, do ponto de vista antropológico, enquanto cesura, ela também traz a marca de uma outridade crucial, a saber, o "inimigo invisível". $\mathrm{O}$ vírus aponta que há um substrato, na tensão entre vida e morte, que nos aproxima, 
nos assemelha, nos torna familiares no contexto da pandemia. Congregada a essas reelaborações do nosso senso de pertencimento, há a deflagração cultural de um horizonte comum em que se conta com as performances de pessoas preocupadas com o bem estar coletivo, as quais, harmonizadas entre si, são convidadas a engajarem-se nos processos de incorporação das diretrizes sanitárias. Por outro lado, tal engajamento é provocado pelo que consideramos como desamparo, isto é, a produção de uma vivência de vulnerabilidade, desprovida de garantias na outridade social mais próxima e nas instituições. O desamparo indica aquilo que se perfaz como lacuna e abismo nas relações humanas. Ele seria próprio à não elaboração e encaminhamento das demandas emergentes por afetos próprios ao conflito entre vida e morte.

As orientações para se gerir a crise pandêmica têm sido transmitidas em meio a impasses de ordem ideológica, política, moral, além de desnudar assimetrias estruturantes de nossa organização social, pelas quais determinados corpos e subjetividades são mais expostos que outros a efeitos nefastos. Isso também se relaciona ao desnivelamento na adesão às políticas de gestão do cotidiano institucionalizadas como mecanismos de controle da pandemia, intervindo, portanto, nas vivências singulares do problema.

Nesse sentido, os ruídos e os desencontros entre as estratégias discursivas ressonadas pelas variadas agentividades políticas acerca da pandemia expõem, visceralmente, a desarticulação e segregação emblemáticas das formas de organização da vida mais recentes. As marcas de um modelo subjetivo de autocentramento a que até então vínhamos atendendo, mobilizado(a)s pelas gratificações capitalistas em reconhecimento ao nosso desempenho individual (Han, 2008), têm se revelado, em sua crueza, nas dificuldades de negociação entre as diversas narrativas elaboradas acerca dos episódios atuais. Por consequência, nossas projeções sobre o porvir tornam-se cada vez mais colonizadas pelo desolamento, justamente pela quebra de um "circuito de afetos" politicamente mobilizado (Safatle, 2019) que até então amparava nossos modos de existência e formas de vida.

É precisamente pelas lacunas de um cenário social quanto à promoção da circulação de afetos propulsores, impulsionadores, que buscamos perceber a sociogênese de uma expressão de desamparo na experiência da intimidade, num esforço correlato ao de identificar os recursos pessoais para a produção de sentido em meio a um ambiente de restrições e de esvaziamentos de diversas ordens. Tal experiência de estar à deriva leva-nos a indagações em torno das respostas pessoais e produções de si acessíveis nessa cultura pandêmica. A ressignificação dos vínculos provocada pelas recomendações de distanciamento social - dos laços mantidos, imaginados, reestabelecidos, ou mesmo rompidos na esfera domiciliar - nos conduzem ao estudo dos sentidos produzidos pela pessoa quando do confronto consigo mesmas ao longo das vivências do confinamento doméstico.

Somadas a essas questões, nossas primeiras compreensões das morfologias da intimidade do confinamento nos levam a reconhecer a expressividade do corpo como recurso fundamental de produção de sentido, uma espécie de ancoradouro dos processos de endereçar-se a si mesmo(a) em meio a esvaziamentos de diversas ordens, vindo a ser fortemente convocado na intimidade da reclusão domiciliar. Diante disso, constituem-se como questões norteadoras da presente discussão dois eixos da intimidade confinada: (a) Como as vivências de desamparo, situando-o como espaço de fratura ética sobre o mundo outrora idealizado como sistema de proteção, capitaliza tensões e significados produzidos sobre o cotidiano, o cuidado de si e do(a) outro(a)? (b) Como a corporeidade 
se configura enquanto campo de apaziguamento ou supressão diante da experiência temporal incômoda que é fomentada pela suspensão da rotina?

Esta discussão realiza-se a partir da incursão em três diários de moradoras de Pernambuco confinadas durante a pandemia.

\section{Intimidade na atualidade e sua singularidade na cultura emergente da pandemia}

No contexto da atual crise sanitária, a recomendação das medidas de isolamento social intensificou o lugar da virtualidade digital na vida cotidiana. Para uma parcela da população, cujo trabalho é possível de ser realizado à distância, por exemplo, a vida off-line se tornou quase um souvenir de um mundo pré-viral, dadas as medidas preventivas de contaminação nas formas de circulação social dos corpos, das superfícies, dos contatos.

Neste processo, poderíamos indagar: como se situaria a intimidade num momento em que a casa se assenhora, como célula produtiva do espaço social, dos seus moradores? Como pensar o espaço da intimidade quando a privacidade representada pelo espaço doméstico - que até então poderia ser pensada como um tecido íntimo dos compassos pessoais mais resguardados das demandas da outridade social - é também agora regulada pelo tempo do teletrabalho e, para alguns, pela gestão dos cuidados dos seus coabitantes, familiares ou não? Quais seriam as características do registro da experiência íntima como distinta e para além da performatividade da exibição virtual do si mesmo e da produtividade no campo do trabalho? Como articular a experiência da intimidade em relação ao campo do não publicável (nem na interface on-line nem nas trocas comunicativas off-line)?

Desta forma, propõe-se que, se por um lado, o mundo público guardaria uma relação coetânea com o surgimento da esfera privada na modernidade, por outro lado, a intimidade não seria redutível à privacidade, como um sinônimo. Na presente leitura, compreende-se que a intimidade é uma experiência que modifica as formas de participação junto às malhas ritualísticas, produtivas e temporais do cotidiano. Em outras palavras, se a ordinariedade da vida cotidiana é uma malha sociocultural que produz ritmos, cadências, um conjunto de regularidades aos circuitos de ações coletivas, a intimidade seria uma dimensão processual própria à reconstrução do vivido, um modo de inquirição sobre os signos ambíguos da experiência, de afastamento da imediaticidade do desempenho para o deslizamento subjetivo sobre a outridade das vozes que constituíram a pessoa, ou ainda, sobre as marcas cegas que o acaso promoveu (Rorty, 1999). Sendo assim, o registro da vida privada seria, por um lado, condição de possibilidade histórica para emergência da esfera da intimidade, mas não seriam sinônimas em termos de sua compreensão sobre a subjetividade (Pinheiro, no prelo).

O mundo privado pode ser publicável, constitui-se como signo e rubrica do "si mesmo”, mas a intimidade não, uma vez que esta última seria processual-dialógica, marcada pelo esforço de espreitar os pontos cegos da vida (Bakhtin, 2006) em relação às forças da ordinariedade da vida cotidiana. É importante destacar que o que reconhecemos como "esfera do íntimo" é necessariamente um campo intersubjetivo, produzido pelas refrações de significados e ressonâncias afetivas das outridades em nós.

À luz do 'Construtivismo Semiótico-Cultural' (Simão, 2010), considera-se que o cenário da pandemia provocou uma espécie de convocação a novas formas de experiência da 
intimidade, enquanto um campo sensível a ser problematizado. A intimidade requer sua compreensão como um processo de permanente tensão e mudança, marcada pela contingência fundante da psique de ser-com-os-outros e das outridades-em-mim. A intimidade, portanto, pode ser pensada como uma espécie de diálogo interior marcado pelo exercício de produzir, através de um afastamento da imediaticidade do cotidiano, um excedente de visão estético-interpretativo (Bakhtin,1990) sobre a ordinariedade da vida, instaurando uma outra temporalidade dos ritmos inerentes aos modos de elaboração do eu. A intimidade seria caracterizada enquanto zona afetiva intermediária e criativa-perspectivante do vivido.

Na singularidade da pandemia como irrupção do desconhecido na cultura, as vivências da quarentena modificaram dois eixos fundamentais no dinamismo das relações eu-outro-mundo, a saber: (a) os modos e qualidades de distribuição dos investimentos afetivos em si e nas pessoas, que tornam-se intensificados na vida confinada ao domicílio; (b) a experiência do tempo marcado pela incerteza sobre o futuro, como também, pela alteração dos ritmos de continuidade e descontinuidade no trabalho, na convivência familiar e seus distanciamentos, e na duração de vivências afetivas interiores intensificadas pelo confinamento.

Uma hipótese a ser empreendida é que a intimidade, enquanto construção dialógica específica, seria acionada particularmente face às experiências de estranheza, de inconsistências vivenciadas no eu, ante os impasses próprios à natureza heteroglótica e, por vezes disruptiva, da vida social. Neste trabalho, toma-se como pressuposto que a emergência do novo na cultura requer que a entendamos como inerente à transformatividade de significações na borda simbólica na relação eu-outro-mundo (Simão, 2010). Esta borda relacional entre a outridade e o eu pode ser pensada, especialmente, em momentos inesperados como a pandemia, como uma região semiótica limítrofe e porosa, prenhe de sentidos nebulosos produzidos pela irrupção inquientante/descentradora (Simão, 2003) daquilo que surpreende e escapa às significações e saberes prévios à emergência da estranheza.

\section{Incorporações do desamparo na emergência da intimidade confinada}

Ao situarmos o vivido corporalmente como uma das nuances da experiência do confinamento, cabe compreender os sentidos que a pessoa passa a atribuir ao seu corpo mediante os novos modos de engajamento no mundo prático da vida exigidos pelo cenário pandêmico. Ou, para além disso, reconhecer o corpo como reflexionante, local de produção de significados e de construções enunciativas. Por tal direção, entende-se, aqui, que mesmo a situação de reclusão doméstica não deixa de falar de "um Eu engajado em um certo mundo físico e inter-humano" (Merleau-Ponty, 1945/2006, p. 121) que segue em seu movimento em direção ao mundo. Logo, tal condição também não suprime sua capacidade de afetar e ser afetado.

Em sua Fenomenologia da Percepção, Merleau-Ponty (1945/2006) apresenta-nos um corpo como uma base e como destino. O corpo é o veículo do ser no mundo estando, por isso mesmo, destinado ao mundo.

A suspeição do corpo estabelecida pela perspectiva cartesiana pauta-se na associação da dimensão do sensível e dos sentidos à irracionalidade, e, portanto, na ideia de que estes últimos não garantem o acesso à verdade das coisas que se busca conhecer. Ao largo dessa referência, Merleau-Ponty localiza o conhecimento produzido a partir das experiências do 
vivido corporalmente, contrapondo-se a uma suposta supremacia da razão instrumental e à concepção de um conhecimento verdadeiro e universalizante acerca do mundo e das coisas. Afinal, uma vez que nossas trajetórias corporais estão constantemente lançadas ao movimento espontâneo que o autor expressa na noção de "ser no mundo", o conhecimento que emerge daquilo que experimentamos corporalmente é igualmente inacabado, incompleto, passível de ser reelaborado.

O filósofo nos leva a entender, também, que, em nossa abertura para o mundo, nos deparamos com barreiras objetivas, sobretudo ao referir-se à existência de um "mundo cultural” em que estamos imersos. Reconhece-se, portanto, as interferências da cultura que atravessam as nossas percepções, bem como as forças sociais que, por vezes, violentam o movimento espontâneo da pessoa-com-seu-corpo no mundo. Assim, em nossas trajetórias corporais, estamos em relação com significações e representações construídas socialmente, que muitas vezes nos condicionam a dar respostas habituais às solicitações que nos são feitas em nosso engajamento no mundo, como que num apego a esquemas práticos.

Mas, a despeito dessas interpelações, a intencionalidade da pessoa é mantida, uma vez que a experiência corporal continua a ser formuladora de sentido. É por essa direção que as experiências do ser-no-mundo são sempre passíveis a reelaborações, não tendo esgotadas as significações de suas trajetórias. Disso resulta que, tanto podemos fixar-nos em modos de agir habituais quanto produzirmos novas respostas subjetivas a partir do vivido cotidianamente. Esse ponto é fundamental, considerando a experiência da estranheza subjacente ao fenômeno da pandemia que envolve tanto a gestão da rotina por meio de saberes prévios quanto uma reorganização da existência.

Tais considerações podem se configurar, também, como chave compreensiva das elaborações de significados construídos num cotidiano de corpos sem toques mútuos e que, no entanto, permanecem articulados a partir de um cenário político comum, o que é sugerido na afirmação: "justamente porque pode fechar-se ao mundo, meu corpo é também aquilo que me abre ao mundo e nele me põe em situação” (Merleau-Ponty, 2006, p. 229). Desse modo, mesmo as relações intersubjetivas podem ser lidas a partir dos sentidos mobilizados pela experiência corporal do confinamento, conforme buscaremos discutir através dos enunciados produzidos pelas participantes.

As transformações vivenciadas por uma sociedade implicam uma abertura à produção de outras formas de vida, produzindo inexoravelmente novos modos de circulação dos afetos: "uma sociedade que desaba são também sentimentos que desaparecem e afetos inauditos que nascem” (Safatle, 2019, p. 16). ${ }^{1}$ Faz-se importante voltar a lembrar da indissociabilidade entre a constituição dos vínculos sociais e a capacidade de ser afetado(a), de ser sensivelmente afetado(a). Precisamente pelo envolvimento das sensibilidades, o desamparo pode ser entendido como experiência fenomenológica, aos moldes da fenomenologia corporal empreendida por Merleau-Ponty (2006), dado que os desdobramentos desse evento social não se fazem sem uma reelaboração de sentido pela pessoa que vivencia corporalmente os efeitos da pandemia.

Ao propormos uma indagação sobre a corporeidade produzida por uma afetividade mobilizada também pelo desamparo, vislumbra-se a possibilidade sempre aberta de novos modos de afetação-significação para além das legitimadas socialmente. Adicionalmente às formas de interiorização desses significados, as afetações sinalizam também as estratégias de adequação e de produção de respostas diante dos processos de desterritorialização e de perda das garantias de um contexto anterior, ao qual convencionalmente se atribuía algum 
grau de normalidade. Há um movimento reconstrutivo, um horizonte de possibilidades disponível para a reorganização do mundo com que nos deparamos em nossas trajetórias mundanas e intimamente vivenciadas.

\section{Sobre a abordagem metodológica produtora dos dados}

As discussões sobre os enlaces entre intimidade, corporeidade e desamparo são construídas no presente artigo através da incursão em três diários textuais, produzidos por moradoras do estado de Pernambuco, confinadas durante a pandemia. Todos os procedimentos, instrumentos e termos foram avaliados e autorizados pelo comitê de ética da Universidade Federal de Pernambuco, garantindo-se, assim, todos os cuidados necessários e atenção às eventuais demandas inesperadas das participantes.

Por via da divulgação de convite para participação na pesquisa, feita através das redes sociais virtuais, as três participantes entraram em contato, sinalizando o interesse em contribuir para a investigação. Após leitura do TCLE, foram instruídas a enviarem para as pesquisadoras, por e-mail ou telefone, a cada dois dias, durante duas semanas, um relato de seu cotidiano, de tudo que considerassem significativo de suas rotinas. Na instrução, foi destacada a importância de dizer sobre pensamentos e sentimentos que acompanhassem as atividades narradas. Após quinze dias, foi realizada uma entrevista para ampliar a compreensão da construção do diário. As participantes precisavam estar confinadas há, no mínimo, quinze dias antes do início da pesquisa e ter acesso à internet para envio do material.

A pesquisa geradora dos dados orientou-se por uma abordagem ideográfica e qualitativa. Isto significa dizer que a perspectiva metodológica partiu do lugar da singularidade contínua e discreta dos processos de significação e da emergência do novo como ponto de partida para a construção de conhecimento e generalização sobre as questões propostas, por um percurso muito diferente de uma abordagem estatística, nomotética (Salvatore \& Valsiner, 2010). Esta última estaria mais relacionada à descrição de estados ali aonde se buscou investigar as qualidades afetivas da experiência enquanto processos de significação e afetação produzidos ao longo do tempo de confinamento, inerentes à mutação dinâmica na cultura. Desta forma, compreende-se que é apenas através da aproximação à unicidade da experiência que a ciência psicológica pode acessar dimensões não quantificáveis, conforme indicado nos propósitos da reflexão deste artigo.

\section{Abordagem interpretativa dos dados}

A análise dialógica dos relatos (Lopes-de-Oliveira, Branco. \& Ferraz, 2020) buscou acessar os seguintes aspectos: (a) os principais impasses na manutenção das formas de vida pré-viral; (b) as ambiguidades enunciativas e ambivalências afetivas na construção de alternativas ao período de confinamento na dinâmica ser-com-os-outros e as outridades-em-mim; (c) as formas de vivência do tempo, na reconstrução do passado, nos modos de elaboração de futuros, através também das intensidades do presente vivenciados na corporeidade elaborada simbolicamente nos diários. 


\section{Discussão dos dados}

Apresentamos, a seguir, a discussão dos diários de cada participante. Destacamos que os fragmentos discutidos foram selecionados por sua representatividade no todo dos relatos. Os conteúdos recortados emergiram durante o período de quinze dias, sendo apresentados de modo a manter sua sequencialidade ao longo da produção das participantes, mesclados com compreensões atingidas também por via da entrevista final. As participantes serão apresentadas com nomes fictícios de modo a evitar a identificação.

\section{Rita}

Rita tem vinte e cinco anos, reside com a mãe, é recém-formada em Psicologia e preparava-se para a seleção de residência em Saúde Mental quando foi estabelecida a quarentena. Na ausência de garantias em relação ao futuro que "é um borrão”, Rita revisita desejos antigos como forma de produzir algum sentido na experiência do confinamento. $\mathrm{O}$ antigo desejo de aprender alemão levou-a a se matricular no curso de idioma, que agora tornou-se EAD (Ensino a Distância). É neste contexto que Rita afirma: "O curso de alemão é a minha versão pandêmica de Sísifo...; Sísifo no sentido de ser enfadonho aprender a nova língua nesse contexto, e ainda mais EAD, que eu não sou muito chegada”.

A língua estrangeira emerge então como representante de um campo afetivo da adolescência, do tempo passado. A vivência se torna aborrecida, pois a futuridade é sentida de forma intensificada por sua nebulosidade e, assim, interditada no campo de ação minimamente antevisto. A ambivalência sobre o curso parece um indicador de uma experiência temporal de duração dilatada no presente, em que o passado refugia/reporta prazeres que o futuro ameaça tomar em sua indeterminação.

Os depoimentos de Rita são, a propósito, marcados por uma ambivalência constante entre sofrer pela suspensão de experiências corporais habituais e o incômodo em ficar sob a própria pele. Assim, ao mesmo tempo em que lamenta a sensação de "estar sem chão", expõe o desejo de sustar temporariamente sua existência: "Não queria existir hoje. A vontade é dormir o dia inteiro e tentar ser uma pessoa melhor amanhã".

Ao dizer-se incomodada pelo silêncio das ruas, pelas ausências a que ele corresponde, Rita imediatamente se dá conta do sentido da circulação de seu corpo nessas novas configurações entre público/privado. Na intimidade produzida pelo campo performativo do diário, lê-se:

As ruas estão mais vazias, o que é uma questão extremamente ambivalente: por um lado é ótimo, porque significa que as pessoas têm respeitado a quarentena. Por outro é um pesadelo - especialmente quando se é mulher - porque a sensação é de insegurança o tempo inteiro; sinto medo quando a rua está vazia e vejo um homem. Sair de casa é uma atividade duplamente estressante agora. Não me sinto confortável em sair de short ou sem sutiã - o que era comum antes - ao invés disso me sinto mais "segura" usando roupas mais folgadas e longas (E eu não acho MESMO que a roupa que alguém usa pode influenciar num caso de assédio, mas no momento é assim que me sinto confortável pra enfrentar essa situação). 
Rita compreende que a experiência do estar-na-rua, característica do contexto da pandemia, não se configura necessariamente como a inauguração da vulnerabilidade a que os corpos femininos são expostos nesse espaço. Sua narrativa destaca atualizações de uma performance corporal orientada por códigos generificados que, a seu ver, se faz ainda mais forte no contexto do distanciamento social: para além das máscaras, as roupas também se instauram, aqui, como artefatos incorporados na busca por um mínimo de segurança. Para além do vírus, há outros riscos a serem refletidos, estratégias que necessitam ser adotadas antes de sair de casa.

Em meio às oscilações e mistura de sensações decorrentes do estar-em-confinamento, Rita segue seu cotidiano em busca de algum sentido. Em um determinado dia, afirma: "Tenho feito exercício físico, sinto que ajuda com que meu dia tenha estrutura. Rotina é importante pra mim e tenho me apegado a qualquer coisa que me dê sensação de controle”.

Somado a isso, ela explica que a atividade física lhe fornece outros sentidos da busca por um autodomínio, ao pontuá-la como recurso para equilibrar excessos cometidos durante o confinamento, como a propensão a comer mais do que de costume, apesar de "comer melhor", por estar cozinhando a própria comida. A experiência de ver-se no espelho com maior frequência, justamente pelo fato de estar o tempo todo em casa, a coloca em confronto com dilemas com o próprio corpo que, no entanto, já a acompanham desde antes desse período. A atividade física aparece aqui como recurso de assinalação da sua existência, e também de alguma autoria, vivenciada na intimidade do diálogo interior junto às diferentes vozes reconstruídas e ressoadas no confinamento.

Os registros desses dois últimos dias são como páginas de um manual de sobrevivência à quarentena. Não sei o que seria de mim sem afeto. Sinto a quarentena apertar e não sei que nome dar a esse sentimento, é algo como melancolia, saudade, nostalgia, uma força que impulsiona meu desejo de superar e voltar pro mundo (da forma como ele se apresentar daqui pra frente), enquanto outra não vê sentido em existir nesse mundo. Mais que tristeza, menos que depressão.

Nesta passagem, é interessante o lugar do diário, agora não mais tão estranho como afirmara no início, mas um "manual de sobrevivência". Rita destaca o intrumento da pesquisa como campo de elaboração do vivido em que se via "decaindo", segundo relata na entrevista. Quando indagada sobre o que pretendia dizer por decair, afirma: "decaindo no sentido que eu acho que eu fui ficando muito mais honesta durante esse período. Eu acho que tiveram... sei lá, eu falei que tava tudo confuso, que eu não tava me sentindo muito bem”. Apesar do uso sofisticado da língua portuguesa pela participante, é curioso o uso do verbo decair que, se à primeira vista poderia aludir ao campo do que fracassa, por outro lado, na insistência de seu enunciado, parece também indicar sobre o que decanta, decai, fica como marca própria de si mesma. Retomando o relato do diário, o afeto surge como enunciado seguinte ao manual de sobreviência, um afeto significado como cuidado corporificado, recuperando uma inscrição dialógica da presença do outro, de um outro que alimenta e é alimentado.

No não sentido do acontecimento da pandemia, a escala de afetos parece dizer da nebulosidade do que não se sabe, mas, por isso mesmo, é vivido como intensidades: "Mais que tristeza, menos que depressão". Como parteira das suas palavras, Rita lança-se no esforço de ser intérprete de si, num diário a ser lido pela outridade pesquisadora. 
A dinâmica dialógica de buscar traduzir-se é ação que Rita reporta realizar de forma bastante produtiva para seus dias, como dito anteriormente, como uma intimidade criadora em meio ao que sequestra o campo dos seus sentidos prévios.

\section{Celina}

Celina tem 35 anos, é educadora física e reside no interior de Pernambuco. Neste ano, depois de morar em outro estado, retorna com o desejo de viver com o companheiro, para construir, como escreve em seu diário, "uma VIDA nova literalmente! Rsrs". Os risos que finalizam o enunciado parecem sugerir certa leveza ali onde reconhece uma "coincidência ou ironia do destino". Esta construção maximiza a dimensão tanto inesperada quanto inovadora dos tempos atuais. Inesperada no que se refere ao evento pandêmico, à fratura que se deu nos rumos que sua vida vinha tomando, e inovadora em termos da decisão pela mudança de cidade e inauguração de uma nova trajetória de vida junto ao namorado, com quem se relaciona há mais de um ano.

Seu estilo de escrita de diário é bastante performativo, no sentido de apresentar uma lista sequenciada de suas atividades diárias, de trabalho, encontros virtuais com amigos e familiares, numa narrativa bastante descritiva do seu campo de ação, mas, nem por isso, menos afetiva quando aborda a relação com o núcleo familiar mais próximo. Celina enviou grande volume de imagens cotidianas, como uma espécie de representação imagética de sua rotina. A exemplo de seu relato no diário, temos:

- Continuei minhas leituras no sáb. livro + artigos no

- Passeei aqui na rua com a Xuxinha;

* sempre que retorno limpo as patinhas dela com uma solução contendo água sanitária

- minhas enteadas vieram na sexta à noite pra cá e retornaram sáb. à noite para passar o domingo com a mãe delas (fizemos um almoço no sáb)

- À noite sáb e dom. assistimos uma série iniciamos... sobre efeitos da tecnologia nas relações sociais. Bem interessante! Foi indicação!

ontem... Dia das Mães falei c minha sogra, tia/madrinha e algumas amigas por chamada de vídeo

É interessante notar que, em sua lista de atribuições, por mais de duas vezes, em diferentes diários, destaca higienizar as patas da cachorra, como se de certa forma, no endereçamento descritivo de seu cotidiano à pesquisadora, ficasse vigilante sobre a observância dos cuidados de limpeza. No isolamento, Celina parece construir uma rotina intensa de cuidados de si e de pessoas significativas de seu convívio através da mediação virtual. São muitas as imagens que envia em diálogo ou em atividade física remota com alunas antigas ou da família. A possibilidade de estar-com essas pessoas, tal como fornecida pelos recursos tecnológicos, é descrita por ela com entusiasmo. Contudo, não tampona o vazio do inefável, não comporta a falta da experiência encarnada a que estava habituada: "Estou apenas na Educação a distância (trabalho on-line) e fazendo alguns acompanhamentos de alongamentos por videochamada. É um desafio, trabalhar sem o toque e a presença física para possíveis correções e abraços após a aula... mas seguimos nos reinventando”. 
Outros sensos de presença, relacionados a momentos mais antigos de sua vida, resistem nas suas elaborações íntimas. No contexto do relato acerca do cotidiano de suas interações no período próximo ao dia das mães, Celina fala de sua mãe como alguém que lembra todos os dias, e ainda enfatiza que "tudo lembra nossos momentos". Neste instante do relato, narra sua gratidão pelo que nomeia como "ensinamentos deixados". A mãe falecera num atropelamento e, juntamente com essa morte, dá-se a perda da figura paterna, não por motivo de falecimento, mas por abandono afetivo. Em seu diário, escreve: "meu pai é meio sem noção e até meio frio pra questões familiares...”. Na entrevista, a participante chega a indagar sobre como ela, aos dezenove anos, não percebera a precariedade afetiva do pai, o que a fez muito jovem procurar sua autonomia financeira e ver-se como responsável pelo irmão mais novo quando ele sofre de uma grave crise psíquica. Na intimidade dialógica da escrita, na semiose afetiva da saudade materna, mostra suas fotografias de infância junto à mãe.

A outridade paterna é evocada no diálogo íntimo de suas memórias com a marca ambivalente de um pai vivo, mas que não exerceu o cuidado paternal. Apesar do pouco contato, se angustia por não ter notícias de seu estado, o que tem lhe provocado, ao longo da quarentena, uma inquietação.

É porque painho é complicado mesmo. Ele nunca foi muito próximo à gente e parece que ele não se preocupa muito com a nossa preocupação, na verdade. Pra ele tá tudo bem, tá tudo certo. Enfim, e espero que realmente ele esteja cumprindo a quarentena, que não esteja saindo de casa, já que ele tá no grupo de risco.

Torna-se curioso notar a emergência da expressão "painho" e a recorrência da palavra "enfim" ao longo do seu diário. Apesar da ambivalência, o diminutivo alude a certo registro afetivo gerador de efeito de enigma para a participante, a que o seu "enfim" tenta estabelecer um corte, sem olhar para trás. Ao mesmo tempo, a preocupação com a figura paterna retorna na formação íntima de seus afetos. A angústia pela vulnerabilidade do pai e a dúvida quando este deixa de dar notícias reportam a essa intimidade, intensificada na pandemia, que coloca a todos sob o potencial desamparo de ser-com-os-outros e os outros-em-mim. Celina relata então que ele está sozinho e que evita ver noticiários para não lembrar dele. Podemos indagar se evitar a lembrança espelha a confrontação com a vulnerabilidade por ela vivida quando mais jovem e que deixa suas marcas na atualidade de suas escolhas. Ela predica sua atitude sobre a evitação dos noticiários como "placebo", uma "autoenganação”, de acordo com suas palavras, acerca das angústias sobre o pai. Recupera que agora estava no momento mais voltado para si e para a construção de sua própria família, de construir sua própria vida. Afirma então: “A vida é feita de escolhas!”. Estas escolhas trazem a ambiguidade das marcas que não escolheu em sua história de vida e a vida que teria escolhido para si, ainda que interpelada pela intimidade do momento pandêmico.

Sendo assim, apesar da quarentena, a futuridade junto ao companheiro parece ser um suporte ao atravessamento da experiência que a torna confiante em seu futuro. Dentre as diversas afinidades pontuadas, o gosto pela prática de atividades físicas, que agora podem realizar juntos, também reafirma seus vínculos no contexto do confinamento. Os diversos registros da rotina de exercícios do casal intentam dar conta de ilustrar as narrativas de Celina quanto à cumplicidade entre eles. Além disso, em termos de uma morfologia da intimidade, parece que o corpo vigoroso, performativo, desempenha um campo de responsividade para a fragilidade e a história que tais corporeidades abrigam. Como um corpo escrita 
de si, a prática de exercícios no momento da quarentena, se por um lado é recomendação de saúde e prática profissional, por outro, figura uma performance de intimidade do casal, uma linguagem corporificada e compartilhada do desempenho energético.

A imagem da planta da casa que pretendem construir parece uma síntese dessa âncora que, em meio à atualidade pandêmica, se oferece como uma gestação de si mesma, livre do fantasma da responsabilidade sobre os outros familiares (pai, irmão) e mais assenhorada de um lugar próprio, ainda que desenhado na planta de uma casa.

\section{Ingra}

Ingra tem 42 anos, é casada, advogada, e tem um filho de 6 anos. Seu estilo narrativo pode ser lido como um subjetivismo de fresta produzido entre pequenas janelas/aberturas de muita intensidade afetiva por entre os múltiplos compromissos cotidianos. O dispositivo dos diários de pesquisa parece ter produzido esse lugar de abertura semelhante ao que acontecia quando se deslocava fisicamente durante as atividades entre um lugar e outro no mundo pré-viral. Os relatos de Ingra são fortemente marcados por referências pelas quais evidencia sua saudade de transitar em outros espaços para além dos da casa. Sente falta de ver carros e pessoas nas ruas, pelo que solicita o testemunho do marido, que continua trabalhando e, portanto, circulando em ambientes extradomésticos.

Meu marido sai todos os dias, né, como eu já disse. Então, ele não tem essa percepção muito aflorada. Quando ele volta, eu sempre pergunto "E aí, como é que tava a rua?"; e ele não entende por que eu pergunto. Porque é muito importante pra mim que tou há 2 meses sem ver os carros andando, sem ver as pessoas andando.

Os momentos de deslocamentos, em que andava na rua, eram só seus. Neles, vivenciava o seu próprio ritmo, em que o olhar podia vagar pela rua em liberdade, agora solapado pelo confinamento e as demandas produtivas entre trabalho, casa e cuidados do filho. Sobre o instrumento da pesquisa, conclui um dos seus primeiros relatos com as seguintes palavras: "Eu gosto de fazer esses depoimentos e é engraçado que eu, nessas horinhas, eu penso naquela música lá de Marisa Monte: 'Hoje eu contei pras paredes coisas do meu coração’. Canto mal, né?”

Neste fragmento de música, a metáfora do enamoramento parece indicar que a atividade da pesquisa produz um campo de elaboração de intensidades que vibram no confinamento, na concretude dos entreparedes, daquilo que insiste em ser dito, articulado. Poder se escutar como uma voz autônoma gera efeito de contentamento em meio ao sufocamento descrito sobre as demandas diárias. O cansaço é tema recorrente de suas elaborações. "Tenho me sentido exausta constantemente e não vejo oportunidades para descanso", afirma.

Neste enunciado, juntamente com outros mais extensos, Ingra aborda uma espécie de expropriação do tempo de si pela invasão das demandas de cuidado das outridades significativas (sogros, filho, casa, marido). Um tempo "de nada para fazer", como descrevia, livre da gramática do desempenho; um nada em que o registro do mais próprio poderia repousar livre da gramática dos outros, num diálogo íntimo com a pura possibilidade. Neste cotidiano, Ingra sente uma espécie de dilatação do tempo presente, mas, mais que isso, uma multiplicação de suas frações pela intensificação da vivência do confinamento 
e incerteza sobre seu término. "Parece que foi há 5 anos atrás algumas coisas, parece que o início do confinamento, embora tenha sido há 60 dias, foi há muito mais tempo (...) Meu Deus, quando isso vai acabar?”, diz.

Isso tem me angustiado bastante. Pessoalmente, ficar em casa é ruim, você não sabe como vai ficar a questão de saúde e no trabalho, porque o volume tá aumentando consideravelmente. Todos os dias tem um novo relatório, a gente precisa se reinventar enquanto negócio, enquanto profissional. A competição é extremamente acirrada dentro e fora.

O peso das adaptações no trabalho geradas pelo confinamento, adicionadas à angústia das atenções na educação do filho, parece formar uma conta entre descanso e atenção que não fecha. Entre dormir três dias seguidos, trabalhar "e ter um esforço pra poder não fazer com que ele [o filho] se sinta um intruso", dá-se a produção de uma corporeidade extenuada, mobilizada pelo impasse entre a maternidade e o sistema de produção vivido de forma ainda mais agressiva, dadas as condições do confinamento. Ingra se comove com o pedido do filho, que gostaria de ganhar de presente de aniversário a permanência dela pós-quarentena em regime de trabalho remoto.

Ele dizer que não quer nunca que a quarentena acabe me faz ficar pensando “Caramba, essa correria toda pra onde?”. Muito do trabalho hoje é pensando nele, pensando nas coisas que ele precisa, mas ele também precisa de mim. Como é que eu posso, depois da quarentena, conciliar isso? Suprir as necessidades materiais dele e a minha presença?

Nestas perguntas fabricadas pela intimidade confinada dos conflitos em tempos pandêmicos, Ingra mergulha na reflexão do propósito da agitação e do movimento produtivo incessante, nas relações entre materialidade e presença. O impasse enunciado no diário dispara um conjunto de questões sobre a ambiguidade das mensagens provocadas pelo outro.

Eu quero mudar esse mundo, mas se o meu trabalho não mudar, se a escola que o meu filho estuda não mudar, como é que eu vou mudar? Algumas coisas, algumas amarras eu preciso tirar por mim mesmo, mas são decisões que não impactam só a mim. São decisões que impactam toda a minha família. Então, como é que eu faço isso? Eu vou mudar à força? Vou me libertar do sistema? Mas eu tenho coisas pra fazer, obrigações pra cumprir. A gente tem que parar com a utopia que alguém vai fazer a mudança por nós. Se todo mundo fizer a sua própria mudança no seu micro universo, eu acho que as coisas acabam mudando, melhorando. A proposta é que seja para melhor, mas eventualmente pode acontecer uma piora, mas assim, eu sempre acreditei muito nisso, que cada um é o senhor do próprio destino e que a gente tem que arranjar uma forma de impor o nosso destino.

Nesta elaboração, Ingra se pergunta sobre suas possibilidades de operar uma mudança, enunciada como um signo aberto, transitivo, quase como pura possibilidade. O "sistema" aparece como aprisionante em que a "imposição do destino", ao invés de surgir em sua fala como algo predeterminado, surge como construção ativa do que deseja, do que procura. Na entrevista, elabora uma trajetória de muita superação de situações de perdas 
vivenciadas em posição social e justifica o termo imposição como determinação de sua força ante a resistência do mundo. Sua intimidade é, assim, construída por um jogo interior de vozes com forças autônomas donde busca construir, entre frestas, a sua própria voz.

Todo dia eu olho pro campo ali do futebol e fico com aquela apreensão que se um dia começarem a fazer um hospital de campanha, tudo fica desesperador demais. Então, o meu, o meu balanceador de desespero é olhar pro campo e ver que só tem um campo ali, que não tem nenhum hospital de campanha ainda. Então hoje eu tirei a foto só pra poder fazer parte aqui do nosso depoimento e penso assim “tá tudo bem, só é um campo".

A figuração do desespero ganha nesta construção enunciativa uma representação tão imaginada quanto percebida, e que participa de suas sensações de risco e de segurança. Neste artifício da intimidade criadora sobre a ambiguidade dos signos do mundo, mundo que fornecia saberes que a protegiam das ameaças desconhecidas, a visão do estádio de futebol da varanda da sua casa dá forma ao inimigo invisível: se o campo está vazio, está tudo bem; se nele observa um hospital de campanha, o desespero está fundamentado. Em outras palavras, Ingra organiza seu campo perceptivo sobre o vírus através de um outro campo, um campo de futebol que é reconstruído semioticamente a partir de sua percepção que já se constitui como interpretação, uma visão que já é reconhecimento, uma apreensão potencialmente desesperadora sobre a vulnerabilidade dos corpos ausentes no campo. O desamparo é, assim, a contrapartida de sua criação, que tem a função psíquica de assegurar algum controle sobre a realidade da vida social.

Nos seus diálogos acerca da angústia sobre vida e morte, Ingra relata, quase como uma epifania, o acontecimento corporal do filho que parece dar novos sentidos ao seu cotidiano através da hiperconvivência com a criança:

O dente de Lírio caiu. Então é engraçado, a vida segue, a vida não tá parada porque a gente tá em quarentena em isolamento. Então o dentinho dele caiu, aí é o terceiro dentinho dele que cai. Ele mesmo tirou. Você vê como é engraçado essas coisas. Tipo, tem coisa que tem que fazer mesmo, é a vida normal. Acho que foi em Jurassic Park, uma coisa assim, tipo: a vida arranja um jeito de seguir o seu curso. É meio exagero, meio nerd, mas é bem isso. A vida continua andando.

Acompanhar as marcas da organicidade retratada nessa fase de desenvolvimento do filho confere ao seu cotidiano um senso de fluxo contínuo que parece acalentá-la, ao recuperar certa força da vida, como um "destino que se impõe", de algo que se move. Interessante observar que na narrativa fílmica que irrompe seu enunciado, os dinossauros de Jurassic Park talvez reencenem o drama de uma espécie que também foi transitória e composta por seres extraordinários, que também seguiu seu ciclo de vida e morte. "A vida continua andando", e assim conclui. 


\section{Considerações finais}

Na leitura da discussão supracitada, podemos reconhecer três estilísticas da intimidade, enquanto campo intermediário de produção de sentidos para as inquietações da relação eu-outro-mundo. São elas: a "introspecção da deriva” (Rita); a "performativa” (Celina) e o "subjetivismo de fresta” (Ingra). Estas expressões são pensadas como alegorias que buscam caracterizar diferenças singulares naquilo que coletivamente as atravessa enquanto dinâmica da vida em tempos de pandemia. Na primeira, encontramos como marca um mergulho semiótico na afetividade sem maiores demandas de conciliações pragmáticas ou ainda sem ancoragens em termos de um futuro perspectivado. A "deriva" é pensada como a dispersão dos possíveis em meio ao não saber, ao tédio e à criatividade expressiva marcante da atividade introspectiva. A corporeidade é, assim, tanto plataforma de intensidades de vulnerabilidade quanto de criação de si mesma. Na estilística "performativa”, encontramos uma permanente ancoragem nos afazeres, numa corporeidade quase instrumental ao atendimento de demandas sociais de trabalhos e cuidados, que parece neutralizar ansiedades maiores sobre a futuridade, onde o si mesmo(a) é pensado como uma tensão em fazer-se presente e manter-se vinculada às outridades significativas. Por fim, no "subjetivismo de fresta”, podemos reconhecer um diálogo interior de intensa afetividade que surge no entre atividades, no entre dinâmicas subjetivo-institucionais, numa leitura permanentemente projetiva de uma solução positiva do futuro ante o jogo de forças vivenciado no presente e que encenam tensões antigas do passado de sua trajetória. Em outras palavras, o "subjetivismo de fresta" inclui intensidades introspectivas, mas que buscam uma conciliação/ solução numa futuridade ativamente construída, como também almejado pela estilística "performativa", donde emerge uma corporeidade exaurida, extenuada. Neste sentido, as três estilísticas se tocam nos modos de ficcionar seus futuros, ainda que enquanto não saber (como em Rita), em meio às contingências descentradoras da atualidade que fazem retornar intimamente vozes de suas trajetórias de vida.

A partir da discussão de fragmentos dos diários e entrevistas, torna-se interessante notar o mergulho realizado, cada uma ao seu modo, na construção da atividade de pesquisa. Uma construção muito insólita, pois visava duplamente o mais próprio enquanto vivência do cotidiano e o endereçamento dele a uma estranha leitora, a pesquisadora. Neste processo, a adesão mencionada como "escutar-se", "contar para as paredes coisas do coração", ou mesmo como "manual de sobrevivência”, lançou pistas sobre a abertura provocada pelo dispositivo de pesquisa como sendo campo surpreendente para as próprias autoras dos diários.

Destaca-se que as atividades de falar do dia-a-dia pareceu operar uma perspectivação reconstrutiva e, simultaneamente, criativa, por vezes poética, na produção de uma extraordinariedade gestada na ordinariedade do dia-a-dia confinado. Numa temporalidade distinta daquelas demandadas pelo outro (trabalho, família, casa), o tempo dedicado ao diário se constituiu como de elaboração das ambiguidades e ambivalências inerentes às ressonâncias subjetivas-dialógicas das vozes das outridades conflitivas, em posição de impasse. Neste sentido, poderíamos dizer que certo registro da ficção, não enquanto oposição à realidade, mas como complexificação desta última, interpelava as participantes no esforço de construir significados estáveis para a estranheza e o desamparo da atualidade. $\mathrm{O}$ próprio endereçamento destes conteúdos às pesquisadoras conota o interesse em 
saber-se produtoras de sentido, artesãs do futuro indeterminístico, em meio a uma rotina desestabilizadora dos recursos subjetivos pessoais e sem amparo nas outridades institucionais (trabalho, Estado, família).

As questões das múltiplas feminilidades se intensificaram na intimidade produzida nos diários de confinamento, uma vez que os impasses históricos das relações de gênero se constituem como vozes corporificadas e em permanente tensão nos modos de (re)produção de trabalho e cuidados de si e dos outros. Apesar de não ser o recorte desta escrita, será interessante aprofundar, em um outro estudo, as questões de gênero implicadas na escrita "diaresca” do confinamento e suas estilísticas. Para as pesquisadoras, foi inesperado que apenas mulheres tivessem demonstrado interesse em participar do estudo.

Na nebulosidade dos tempos atuais, podemos pensar que o registro dos diálogos íntimos é um "relicário" do vivido culturalmente no cenário da pandemia e os modos de perspectivação do porvir. Na sociogênese da intimidade confinada, os diários se constituem como testemunhos de processos de mudança potenciais nas relações eu-outro-mundo.

\section{Notas}

1 Torna-se importante destacar que as proposições de Safatle sobre o desamparo surgem nesse texto reconhecendo-se a lacuna da tematização sobre a experiência de vulnerabilidade corporificada, nos pressupostos dialógicos e fenomenológicos que orientaram a presente escrita até aqui. Sendo assim, optou-se por um recorte bem constrito da obra do autor, naquilo que produz efeito de diálogo com as questões percorridas no presente artigo

\section{Referências}

Balkhtin, M. (1990). Art and answerability. Austin/TX: University of Texas Press.

Bakhtin, M. (1999). Towards a philosophy of act. Austin/TX: University of Texas Press.

Bakhtin, M. (1979/2006). Estética da criação verbal. São Paulo: Martins Fontes.

Butler, J. (2019). Corpos em aliança e a política das ruas: notas para uma teoria performativa de assembleia. Rio de Janeiro: Civilização Brasileira.

Han, Byung-Chul. (2017). Sociedade do cansaço. Petrópolis, RJ: Vozes.

Lisdero, P., Brandan, M., Pellón, I., \& Dubois, D. (2017). Entrenando Emociones: reflexiones metodológicas en torno a las nuevas formas de entrenamientos y el trabajo. In C. Gandía (Org.), Metodologías de la investigación: estrategias de indagación (pp. 87-104). Buenos Aires: Estudios Sociológicos.

Lopes-de-Oliveira, M. C., Branco, A., \& Ferraz, S. (Eds.). (2020). Psychology as a Dialogical Science: Self and Culture Mutual Development. Suíça: Springer.

Merleau-Ponty, M. (1945/2006). Fenomenologia da percepção. São Paulo: Martins Fontes. Original publicado em 1945. 
Pinheiro, M. (no prelo).Written under the skin: The challenges of intimacy in contemporary. In J. Valsiner, G. Marsico, C. Cornejo, \& M. Molina (Orgs.), Annals of Cultural Psychology in relation to the issue of Intimacy: $A$ shared part of me. IAP.

Pinheiro, M. \& Mélo, R. (2020). Mutações culturais em tempos de pandemia: Relação eu-outro e a emergência do novo nas formas de vida. CAAE: 30861220.3.0000.5208. Pesquisa aprovada pelo Observatório Covid-19 da UFPE. Recuperado de https://www.ufpe.br/covid-19/observatorio/politicas

Rorty, R. (1993). Contingency, irony and solidarity. Cambridge, NY: Cambridge University Press.

Rorty, R. (1999). Philosophy and social hope. London: Penguin Books.

Salvatore, S. \& Valsiner, J. (2010). Between the general and the unique: overcoming the nomothetic versus idiographic opposition. Theory and Psychology, 20(6), 817-833. DOI: doi/10.1177/0959354310381156

Safatle, V. (2019). O circuito dos afetos: corpos políticos, desamparo e o fim do indivíduo. Belo Horizonte: Autêntica.

Simão, L. (2003). Beside Rupture-Disquiet; Beyond the Other-Alterity. Culture \& Psychology, $9(4), 449-459$.

Simão, L. (2010). Ensaios dialógicos: compartilhamento e diferença nas relações eu-outro. São Paulo: Hucitec.

\author{
MARINA ASSIS PINHEIRO \\ https://orcid.org/0000-0002-4019-0502 \\ Professora adjunta do Departamento de Psicología da UFPE, Membro \\ permanente do Programa de Pós-graduação em Psicología Cognitiva. \\ Endereço: Universidade Federal de Pernambuco (UFPE) - Centro de \\ Filosofia e Ciências Humanas $(\mathrm{CFCH})-\mathrm{Av}$. da Arquitetura $\mathrm{s} / \mathrm{n}-8^{\mathrm{o}}$ Andar - \\ Cidade Universitária - Recife - PE - CEP: 50740-550. \\ E-mail: marinaassis.pinheiro@gmail.com
}

\title{
ROBERTA DE SOUSA MÉLO
}

http://orcid.org/0000-0003-1936-0818

Professora adjunta do Colegiado de Educação Física da UNIVASF, membro do Programa de Pós-graduação em Educação Física da UNIVASF, PE.

E-mail: rdesmelo@gmail.com 


\begin{tabular}{|c|c|}
\hline Histórico & $\begin{array}{l}\text { Submissão: 29/06/2020 } \\
\text { Revisão: 21/07/2020 } \\
\text { Aceite: 22/07/2020 }\end{array}$ \\
\hline $\begin{array}{l}\text { Contribuição } \\
\text { dos autores }\end{array}$ & $\begin{array}{l}\text { Concepção: M.A.P.; R.M. } \\
\text { Coleta de dados: M.A.P.; R.M. } \\
\text { Análise de dados: M.A.P.; R.M. } \\
\text { Elaboração do manuscrito: M.A.P.; R.M. } \\
\text { Revisões críticas de conteúdo intelectual importante: } \\
\text { M.A.P.; R.M. } \\
\text { Aprovação final do manuscrito: M.A.P.; R.M. }\end{array}$ \\
\hline $\begin{array}{l}\text { Consentimento } \\
\text { de uso de imagem }\end{array}$ & Não se aplica. \\
\hline $\begin{array}{l}\text { Aprovação, ética } \\
\text { e consentimento }\end{array}$ & $\begin{array}{l}\text { Foi aprovado pelo comitê de ética da UFPE, parecer de aprovação: } \\
\text { CAAE: } 30861220.3 .0000 .5208\end{array}$ \\
\hline Financiamento & Não houve financiamento. \\
\hline
\end{tabular}

